\title{
CUL4B Gene
}

National Cancer Institute

\section{Source}

National Cancer Institute. CUL4B Gene. NCI Thesaurus. Code C93069.

This gene plays a role in the regulation of ubiquitination. 